\title{
Naprawa odlewów staliwnych typu duplex GX2CrNiMoCu25-6-3-3 metodą MAG drutem proszkowym
}

\author{
Repair duplex steel castings GX2CrNiMoCu25-6-3-3 \\ MAG cored wire
}

\section{Streszczenie}

W artykule opisano wpływ spawania naprawczego odlewów staliwnych na własności i strukturę obszarów napawanych. Badaniom poddano odlewy ze staliwa typu duplex GX2CrNiMoCu25-6-3-3, w których wykonano symulowane wady z wykorzystaniem żłobienia plazmowego, żłobienia elektrodą otuloną ChamferTrode 03 oraz żłobienia elektropowietrznego elektrodą grafitową o średnicy $6 \mathrm{~mm}$. Spawanienaprawczeprzeprowadzono metodą MAG drutem proszkowym Avesta Sheffield FCW 2205-H o średnicy 1,2 mm w osłonie mieszanki gazowej $\mathrm{Ar}+\mathrm{CO}_{2}$ prądem pulsacyjnym. Obszary napawane zostały poddane badaniom wizualnym, badaniom makro, mikroskopowym, pomiarowi twardości oraz ocenie zgodności barwy po napawaniu. Przeprowadzone badania wykazały zachowanie struktury dwufazowej w obrębie SWC oraz w obszarze linii wtopienia, co może wskazywać na małe wymieszanie się spoiwa z materiałem rodzimym. W obszarach napawanych nie doszło do znacznego rozrostu ziarna. Proces spawania naprawczego nie spowodował znacznego utwardzenia w obszarze napoiny i SWC. Barwa napoin naprawczych nie wykazała znacznych różnić w stosunku do materiału rodzimego, co jest ważne podczas prowadzenia prac naprawczych odlewów staliwnych.

Słowa kluczowe: staliwo duplex, naprawa odlewów, spawanie

\section{Abstract}

The article describes the impact of the repair castings on the properties and structure of the deposited areas. The tests were steel castings GX2CrNiMoCu25-6-3-3 duplex in which simulated defects were made using plasma gouging, gouging coated electrode ChamferTrode 03 and electro-air gouging graphite electrode with a diameter of $6 \mathrm{~mm}$. Repair welding was performed by MAG cored Avesta Sheffield FCW 2205- $\mathrm{H}$ with a diameter of 1,2 $\mathrm{mm}$ in the cover gas mixture $\mathrm{Ar}+\mathrm{CO}_{2}$ pulsed current. Welded areas were visually tasted, tested macro, microscopic, measurement of hardness and color conformity assessment after welding. The study showed the behavior of the twophase structure within the SWC and in the fusion line, which may indicate a small mixing the binder with the parent material. In areas of the deposited there was no significant grain growth. Repair welding process did not cause a significant hardening in the weld and HAZ. The color of repair welds showed no significant differ with respect to the parent material, which is important when carrying out repair work steel castings.

Keywords: duplex cast steel, repair castings, welding

\section{Wstęp}

Odlewy staliwne są często wykorzystywane w przemyśle, dlatego ważne jest, aby można było je wytwarzać w stanie, w którym nie wymagają one dużych ilości zabiegów obróbkowych, ale także żeby były tanie w produkcji. Są to dwa główne problemy produkcyjne. Zmniejszenie gabarytów prowadzi przeważnie do wystąpienia wad odlewniczych spowodowanych brakiem zasilenia odlewu w czasie stygnięcia. Także inne czynniki, jak źle zaprojektowany odlew czy urwanie masy formierskiej w czasie zalewania, mogą doprowadzić do powstania wad $[1 \div 2]$. W takich przypadkach stosuje się metody naprawy odlewów m.in. metodami spawalniczymi.

Przez spawanie naprawcze odlewów możliwe są do usunięcia różnego rodzaju wady powierzchniowe i wewnętrzne. Można w ten sposób uzupełnić większe ubytki materiału, co jest szczególnie ważne w przypadku odlewów staliwnych. Spawalnicze metody naprawy odlewów to także łączenie poszczególnych sekcji odlewów w całość. Takie rozwiązanie stosuje się, gdy nie jest możliwe odlanie elementu $\mathrm{w}$ jednym procesie lub gdy gabaryty odlewu są ponad moż-

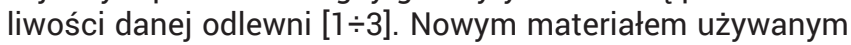
w odlewniach jest staliwo duplex. Staliwo to posiada strukturę dwufazową ferrytyczno-austenityczną, dzięki czemu ma dobre własności wytrzymałościowe oraz jest odporne na korozję. Posiada ono także wady, takie jak skłonność

Mgr inż. Marcin Żuk - Politechnika Śląska 
do pękania oraz wrażliwość na szybkość stygnięcia, dlatego też ważnym zagadnieniem związanym z tym materiałem

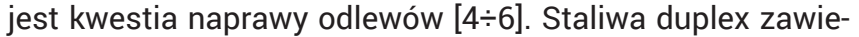
rają przeważnie $21 \div 28 \%$ chromu, $4 \div 7 \%$ niklu, $1 \div 4 \%$ molibdenu oraz do ok. 0,05\% węgla (wyjątkiem jest pierwsza generacja staliwa duplex, gdzie zawartość węgla nie przekraczała 0,08\%). Mniejsza zawartość niklu obniża koszty wytwarzania, dzięki czemu może być ono wykorzystywane na szerszą skalę. Ze względu na skład chemiczny ich spawalność powinna być na poziomie stali austenitycznych. Trzeba tylko utrzymać niską zawartość węgla w materiałach dodatkowych do spawania oraz dobrać odpowiedni skład chemiczny stopiwa do składu materiału rodzimego. W czasie spawania ważne jest to, aby materiał rodzimy nie był zbyt długo przetrzymywany w wysokiej temperaturze $\left(600 \div 1000{ }^{\circ} \mathrm{C}\right)$, ponieważ jest on skłonny do powstania kruchych faz węglikowych m.in. fazy sigma $[4 \div 5,7 \div 8]$. Staliwo duplex może być spawane wszystkimi metodami łukowymi, z tego względu jest to materiał pożądany na rynku, trzeba jednak uważać w przypadku metod niskoenergetycznych, gdyż może wystąpić zbyt duża ilość ferrytu w miejscu spawanym $[8,10]$. W przypadku metody spawania w osłonach gazów ochronnych istnieje możliwość wprowadzenia dodatkowo azotu w miejsce jeziorka spawalniczego, przez co można zwiększyć ilość austenitu w spoinie. W przypadku użycia drutu proszkowego w metodzie MAG, zalecane jest użycie mieszanek $\mathrm{Ar}+\mathrm{CO}_{2}$ oraz zastosowanie urządzeń z synergicznym sterowaniem. Także zaleca się używać niskich energii liniowych spawania rzędu $0,5 \div 2,5 \mathrm{~kJ} / \mathrm{mm}$ [8 $\div 10]$. Spawanie naprawcze odlewów staliwnych przeprowadzane jest przeważnie w celu uzupełnienia nieciągłości materiału, gdzie nie są wymagane bardzo wysokie własności wytrzymałościowe. Może to być np. uzupełnienie ścianki odlewu w celu zachowania szczelności. Ważnym aspektem podczas naprawy odlewu jest odtworzenie ubytku z zachowaniem możliwe najlepiej zbliżonej barwy spoiwa do materiału rodzimego.

\section{Badania własne}

Celem badań było określenie wpływu procesu żłobienia i spawania naprawczego na strukturę i własności staliwa duplex GX2CrNiMoCu25-6-3-3 (skład chemiczny i własności wg normy przedstawiono w Tabl. I i II, a przykładową strukturę na Rys. 1) żłobionych plazmowo, elektrodą otuloną, elektro-powietrznie, a następnie napawanych metodą MAG drutem proszkowym Avesta Sheffield FCW 2205-H o średnicy 1,2 mm w osłonie mieszanki gazowej $\mathrm{Ar}+\mathrm{CO}_{2}$ prądem pulsacyjnym. Skład masowy stopiwa przedstawia Tablica III.

\section{Proces żłobienia}

Do procesu żłobienia użyto odlewów staliwnych ze staliwa duplex GX2CrNiMoCu25-6-3-3. Odlewy staliwne zostały wstępnie poddane procesowi żłobienia w celu zasymulowania wad odlewniczych. Wady odlewnicze wykonano poprzez żłobienie plazmowe, żłobienie elektrodą otuloną ChamferTrode 03 oraz żłobienie elektro-powietrzne elektrodą grafitową o średnicy $6 \mathrm{~mm}$. Na rysunkach 2 i 3 widoczne są symulowane wady po procesie żłobienia w postaci ubytków w materiale, które zostały poddane procesowi spawania naprawczego.

Tablica I. Skład chemiczny staliwa GX2CrNiMoCu25-6-3-3 [12]

Table I. Chemical composition of cast steel GX2CrNiMoCu25-6-3-3 [12]

\begin{tabular}{|c|c|c|c|c|c|c|c|c|c|c|}
\hline \multirow{2}{*}{ Próbka } & \multicolumn{10}{|c|}{ Stężenie pierwiastków, [\%] } \\
\cline { 2 - 20 } & $\mathrm{C}$ & $\mathrm{Cr}$ & $\mathrm{Ni}$ & $\mathrm{Mn}$ & $\mathrm{Si}$ & $\mathrm{Cu}$ & $\mathrm{S}$ & $\mathrm{P}$ & $\mathrm{Al}$ & $\mathrm{N}$ \\
\hline \multirow{2}{*}{ Norma } & $\begin{array}{c}\max \\
0,03\end{array}$ & $5 \div 7$ & $\begin{array}{c}\max \\
1,5\end{array}$ & $2,5 \div 3,5$ & $\begin{array}{c}\max \\
1,0\end{array}$ & $2,75 \div 3,5$ & $\begin{array}{c}\max \\
0,025\end{array}$ & $\begin{array}{c}\max \\
0,035\end{array}$ & - & $0,12 \div 0,22$ \\
\hline $\mathrm{P} 1$ & 0,026 & 24,7 & 6,13 & 1,05 & 0,55 & 3,19 & 0,006 & 0,024 & 0,009 & 0,15 \\
\hline
\end{tabular}

Tablica II. Skład chemiczny staliwa GX2CrNiMoCu25-6-3-3 [12] Table II. Chemical composition of cast steel GX2CrNiMoCu25-6-3-3 [12]

\begin{tabular}{|c|c|c|c|}
\hline $\begin{array}{c}\text { Umowna } \\
\text { granica } \\
\text { plastyczności } \\
\mathrm{R}_{0,2^{*}},[\mathrm{MPa}]\end{array}$ & $\begin{array}{c}\text { Wytrzymałość } \\
\text { na rozciąganie } \\
\mathrm{Rm}{ }^{\star},[\mathrm{MPa}]\end{array}$ & $\begin{array}{c}\text { Wydłużenie } \\
\mathrm{A}^{*},[\%]\end{array}$ & $\begin{array}{c}\text { Udarność } \\
\mathrm{KV}{ }^{*},[\mathrm{~J}]\end{array}$ \\
\hline 480 & 650 & 22 & 50 \\
\hline$*-$ Wartości minimalne & \\
\hline
\end{tabular}

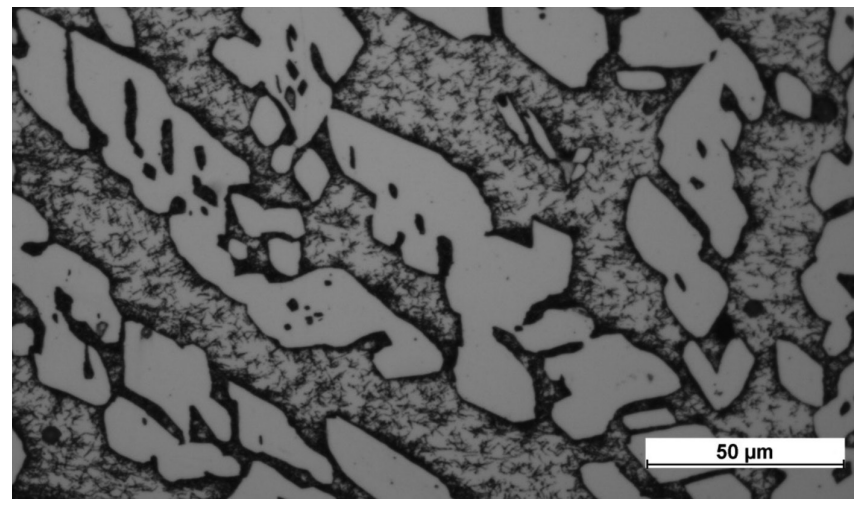

Rys. 1. Struktura ferrytyczno-austenityczna staliwa duplex Fig. 1. Ferritic-austenitic structure of duplex cast steel

Tablica III. S Skład chemiczny stopiwa FCW 2205-H Table III. Chemical composition of FCW 2205-Hw

\begin{tabular}{|c|c|c|c|c|c|c|c|c|c|}
\hline \multicolumn{10}{|c|}{ Stężenie pierwiastków, [\%] } \\
\hline $\mathrm{C}$ & $\mathrm{Cr}$ & $\mathrm{Ni}$ & $\mathrm{Mn}$ & $\mathrm{Mo}$ & $\mathrm{Si}$ & $\mathrm{Cu}$ & $\mathrm{S}$ & $\mathrm{P}$ & $\mathrm{N}$ \\
\hline 0,032 & 23,17 & 9,29 & 0,96 & 3,48 & 0,7 & - & 0,006 & 0,017 & 0,16 \\
\hline
\end{tabular}


a)

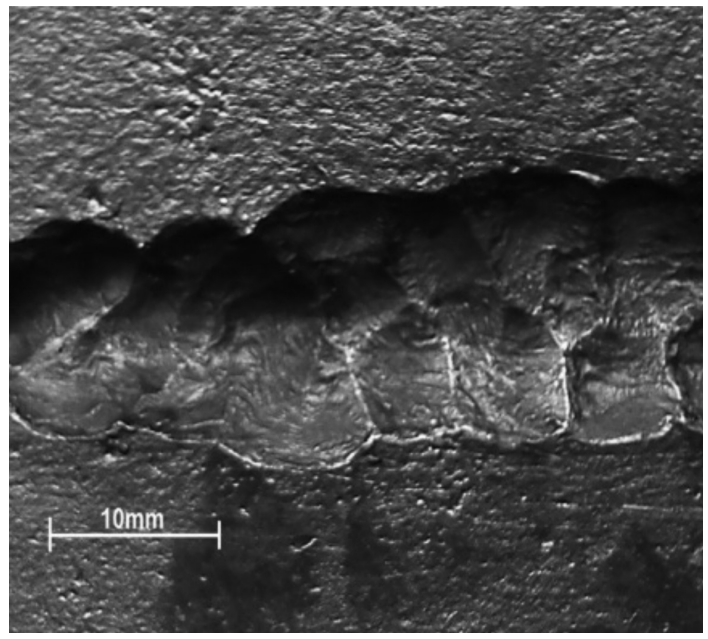

b)

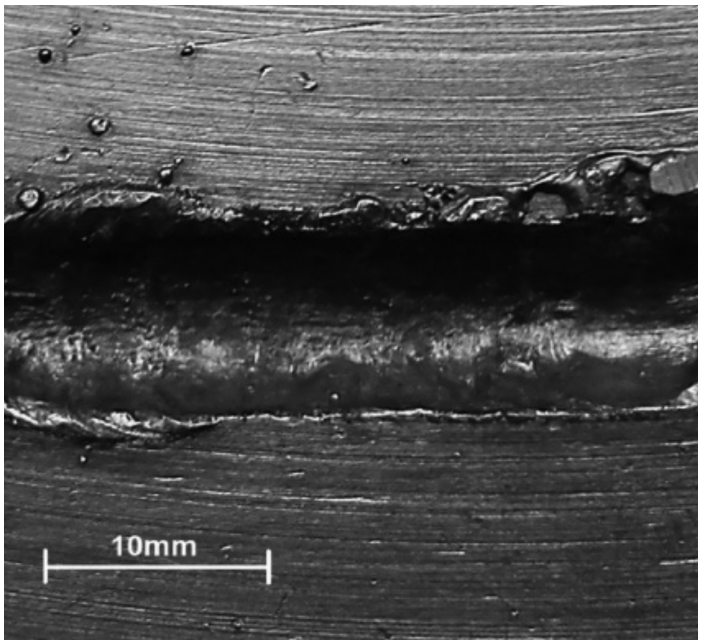

c)

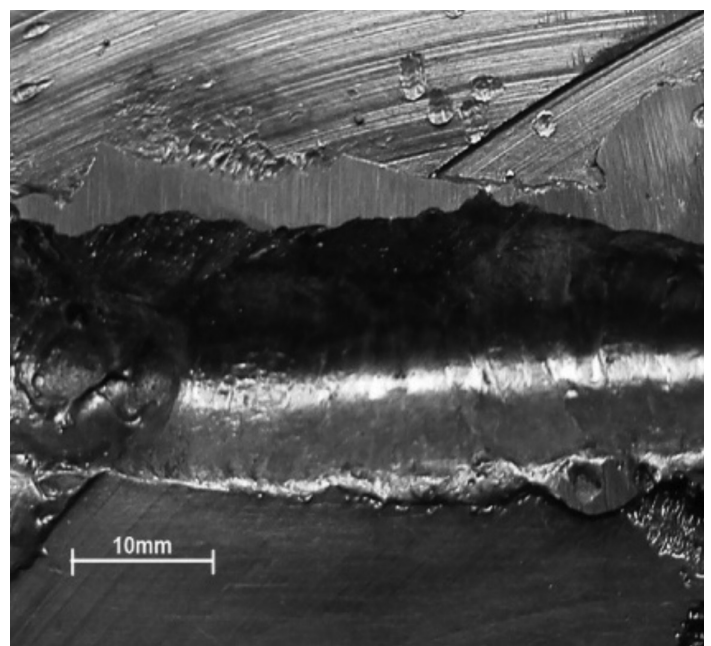

Rys. 2. Symulowane wady wykonane poprzez żłobienie: a) plazmowe, b) elektrodą otuloną, c) elektro-powietrznie

Fig. 2. Simulated faults made by gouging: a) plasma, b) coated electrode, c) electro-air

\section{Proces spawania naprawczego}

Do procesu spawania naprawczego użyto odlewów ze staliwa duplex GX2CrNiMoCu25-6-3-3 z wcześniej wykonanymi symulowanymi wadami. Spawano je metodą MAG drutem proszkowym Avesta Sheffield FCW 2205-H o średnicy 1,2 mm w osłonie mieszanki gazowej $\mathrm{Ar}+\mathrm{CO}_{2}$ prądem pulsacyjnym. Parametry procesu napawania przedstawia tablica IV. Ściegi wykonywano w pozycji podolnej, bez wstępnego podgrzania materiału.

\section{Badania napawanych odlewów}

Odlewy po napawaniu zostały poddane badaniom:

- wizualnym na podstawie wymagań PN-EN ISO 17637:2011, a)

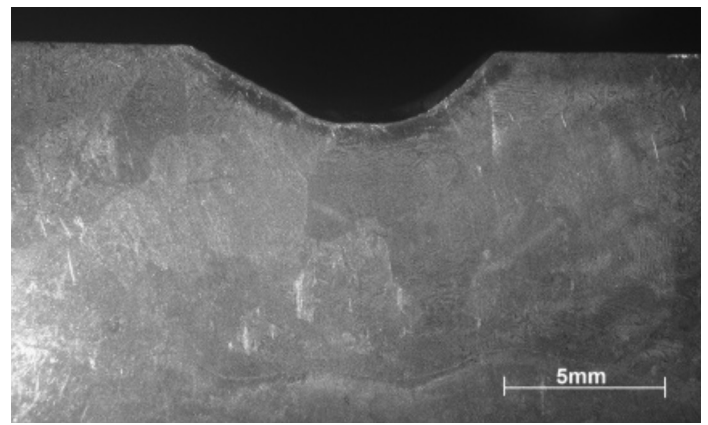

b)

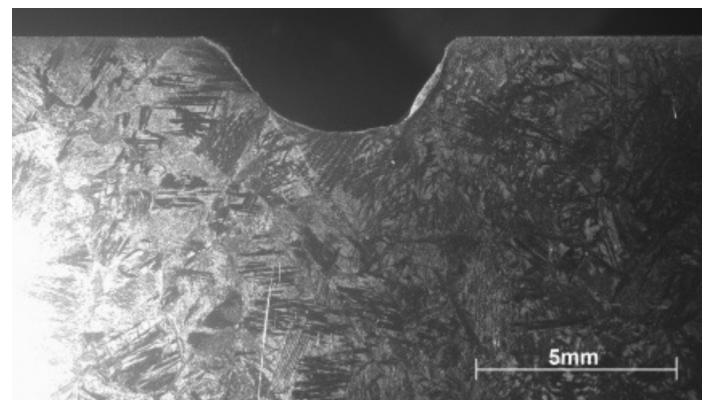

c)

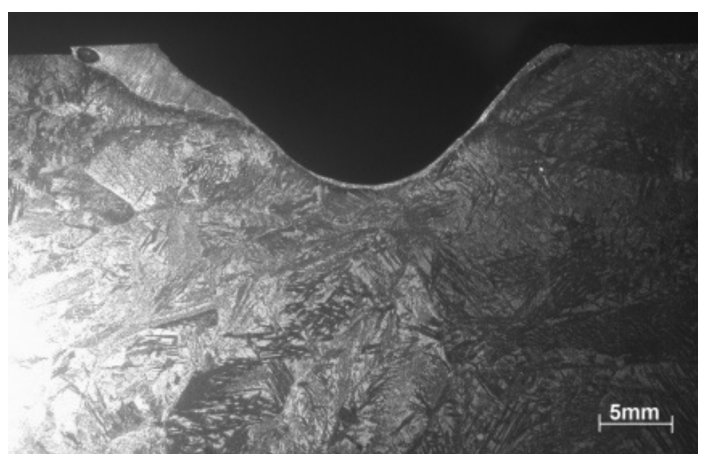

Rys. 3. Widok makrostruktury po żłobieniu: a) plazmowym, b) elektrodą otuloną, c) elektro-powietrznym

Fig. 3. View macrostructure after gouging a) plasma, b) coated electrode, c) electro-air

- metalograficznym makroskopowym na mikroskopie świetlnym Olympus SZX9; próbki trawiono w wodzie królewskiej,

- metalograficznym mikroskopowym na mikroskopie świetlnym NIKON ECLIPSE MA100; próbki trawiono w wodzie królewskiej,

- pomiaru twardości sposobem Vickersa na urządzeniu WILSON WOLPERT 430 zgodnie z wymaganiami normy PN-EN ISO 9015-1. Badania przeprowadzono w jednej linii pomiarowej (Rys. 4).

Tablica IV. Parametry procesu spawania

Table IV. Parameters of the welding process

\begin{tabular}{|c|c|c|}
\hline \multicolumn{3}{|c|}{ Parametry napawania } \\
\hline $\begin{array}{c}\text { Natężenie } \\
\text { prądu I, [A] }\end{array}$ & $\begin{array}{c}\text { Napięcie } \\
\text { łuku U, [V] }\end{array}$ & $\begin{array}{c}\text { Prędkość podawania } \\
\text { drutu V, [m/min] }\end{array}$ \\
\hline 170 & 22,5 & 5,2 \\
\hline
\end{tabular}

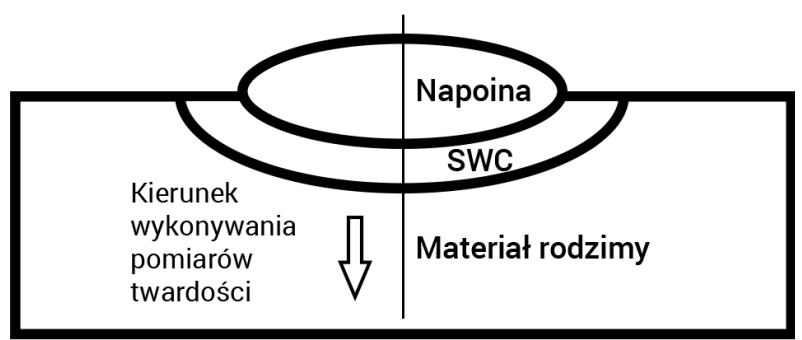

Rys. 4. Kierunek wykonywania badań twardości w napawanym materiale Fig. 4. The direction of testing the hardness of the weld material 


\section{Analiza wyników badań}

Badania wizualne przeprowadzone na napawanych odlewach nie wykazały wychodzących na powierzchnię wad spawalniczych jak pęknięcia czy podtopienia (Rys. 5). Wykonane badania makroskopowe uwidoczniły wyłącznie w jednym przypadku wtrącenia żużla w obszarze linii wtopienia (Rys. 6). W pozostałych przypadkach nie wykryto wad spawalniczych (Rys. 6). Każda napoina spełniała wymagania geometryczne co do szerokości i wysokości lica. Barwa otrzymanych napion nie odbiegała od barwy materiału rodzimego.

Badania mikroskopowe w obszarze napoiny wykazały wy-

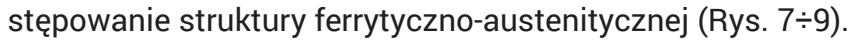
W przypadku SWC oraz materiału rodzimego proces napawania nie wpłynął na zmiany struktury (Rys. $7 \div 9$ ). W tym obszarze została zachowana struktura dwufazowa ferrytyczno-austenityczna, bez rozrostu ziaren. Nie uwidocznił się znaczący rozrost faz niepożądanych, takich jak faza sigma, która wpływa negatywnie na własności obszarów spawanych $[3 \div 5,7 \div 8]$.

Przed przystąpieniem do napawania $\mathrm{w}$ materiale przeznaczonym do badań zasymulowano wady zewnętrzne,
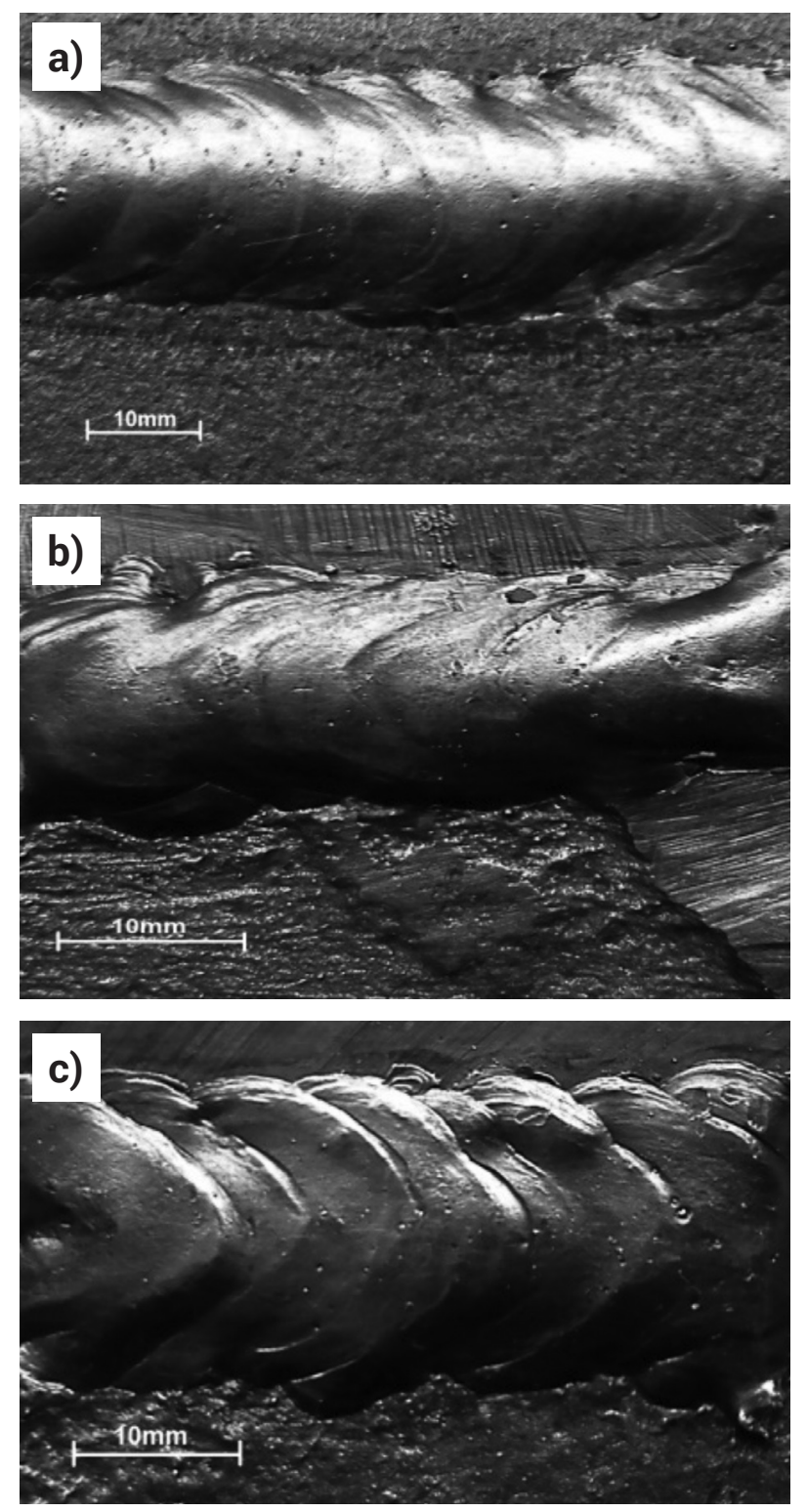

Rys. 5. Widok lica napoin uzyskanych metodą MAG; przygotowanie do naprawy. żłobienie plazmowe, b) żłobienie elektrodą otuloną, c) żłobienie elektro-powietrzne

Fig. 5. View padding weld face obtained MAG; preparing for repair. a) plasma gouging, b) gouging coated electrode, c) electro-air-gouging wykonując żłobienie różnymi metodami. Procesy żłobienia spowodowały zwiększenie twardości materiału w warstwie wierzchniej. W przypadku żłobienia elektro-powietrznego odnotowano wzrost twardości do ok. 500 HV, co jest zapewne wynikiem nawęglenia powierzchni (z elektrody grafitowej użytej w procesie) z jednoczesnym podhartowaniem. W mniejszym stopniu na twardość powierzchni wpłynął proces żłobienia plazmowego (maksymalna twardość wzrosła do ok. $320 \mathrm{HV}$ ) oraz żłobienia elektrodą otuloną (280 HV) [13]. Przeprowadzone pomiary twardości po spawaniu naprawczym metodą MAG (Rys. 10) wykazały wzrost twardości w obszarze linii wtopienia. W przypadku powierzchni przygotowanej poprzez żłobienie plazmowe uzyskano najwyższe twardości na poziomie $285 \mathrm{HV}$, podobne wartości uzyskano w przypadku żłobienia elektrodą otuloną. Najniższymi wartościami twardości w obszarze linii wtopienia charakteryzowały się napoiny przygotowywane do naprawy poprzez żłobienie elektro-powietrzne (255 HV). W każdym przypadku twardość napoin przy licu była nieznacznie wyższa od wartości twardości materiału rodzimego. Wraz z oddalaniem się od lica napoin twardość malała osiągając wartość ok. $240 \mathrm{HV}$.
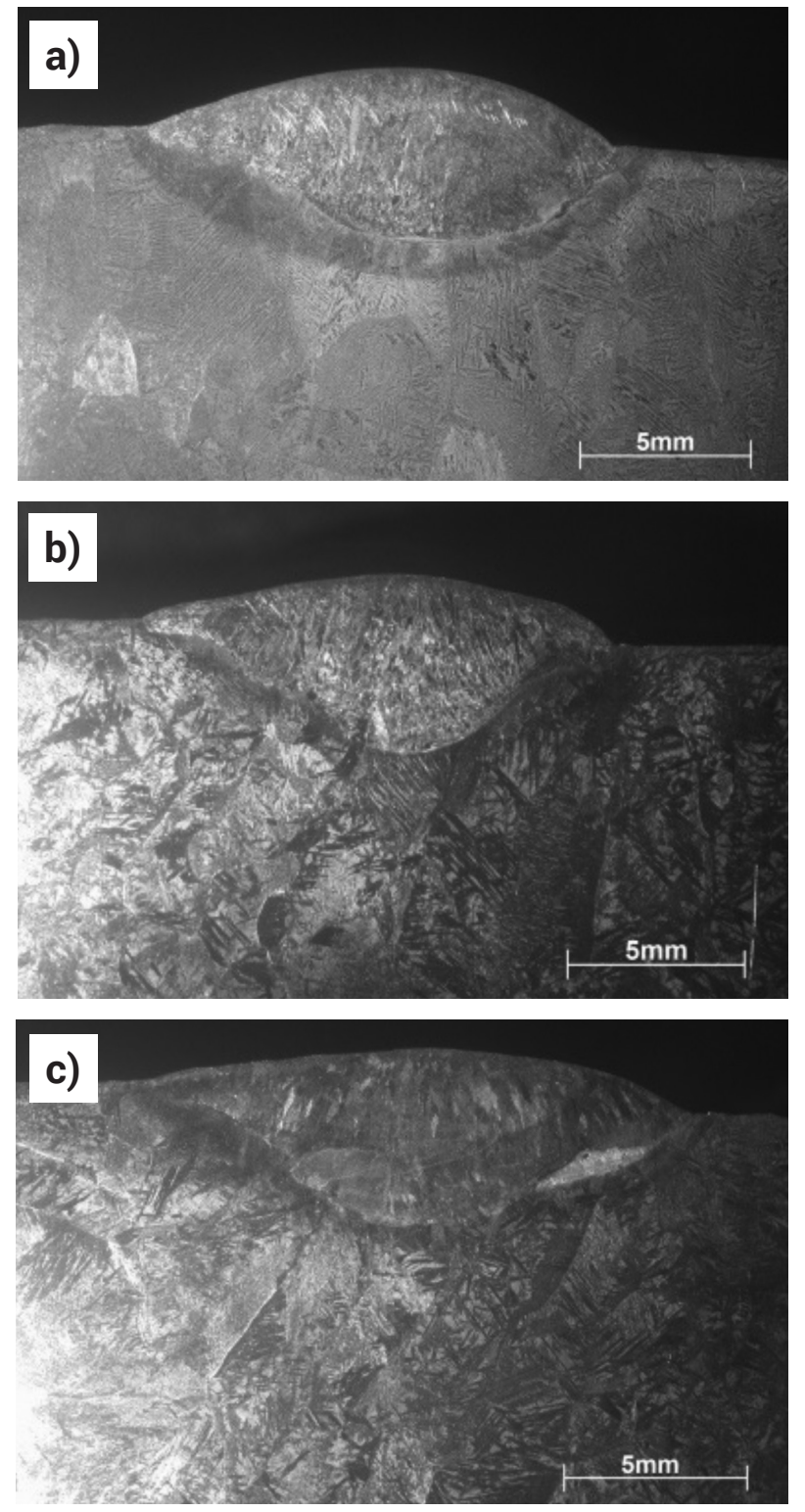

Rys. 6. Makrostruktury napoin uzyskanych metodą MAG; przygotowanie do naprawy. a) żłobienie plazmowe, b) żłobienie elektrodą otuloną, c) żłobienie elektro-powietrzne

Fig. 6. Macrostructure padding weld obtained MAG; preparing for repair. a) plasma gouging, b) gouging coated electrode, c) electro-air-gouging 

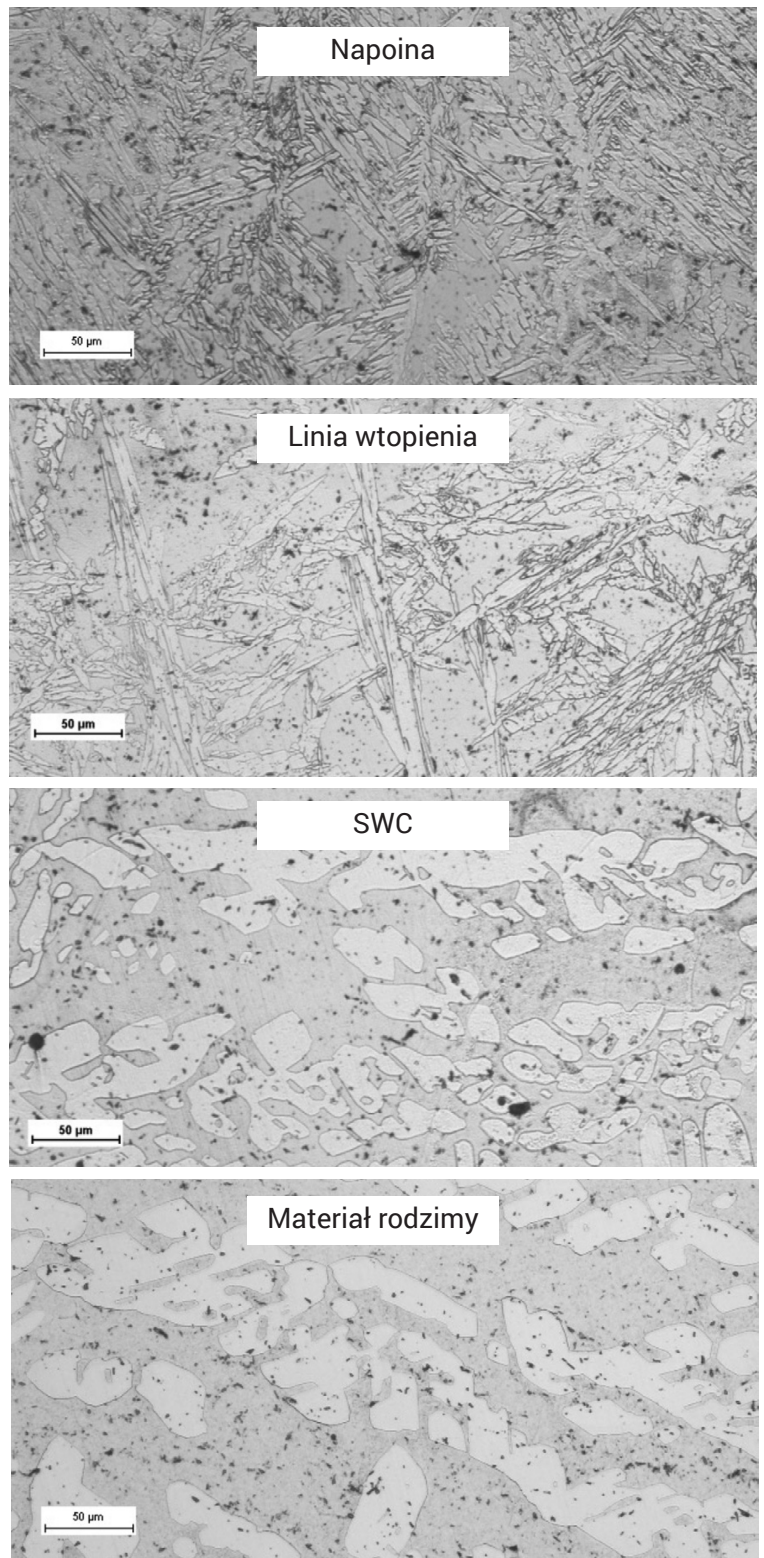

Rys. 7. Mikrostruktury napion uzyskanych metodą MAG; przygotowano do napawania poprzez żłobienie plazmowe

Fig. 7. Microstructure padding weld obtained MAG; prepared for weIding through plasma gouging
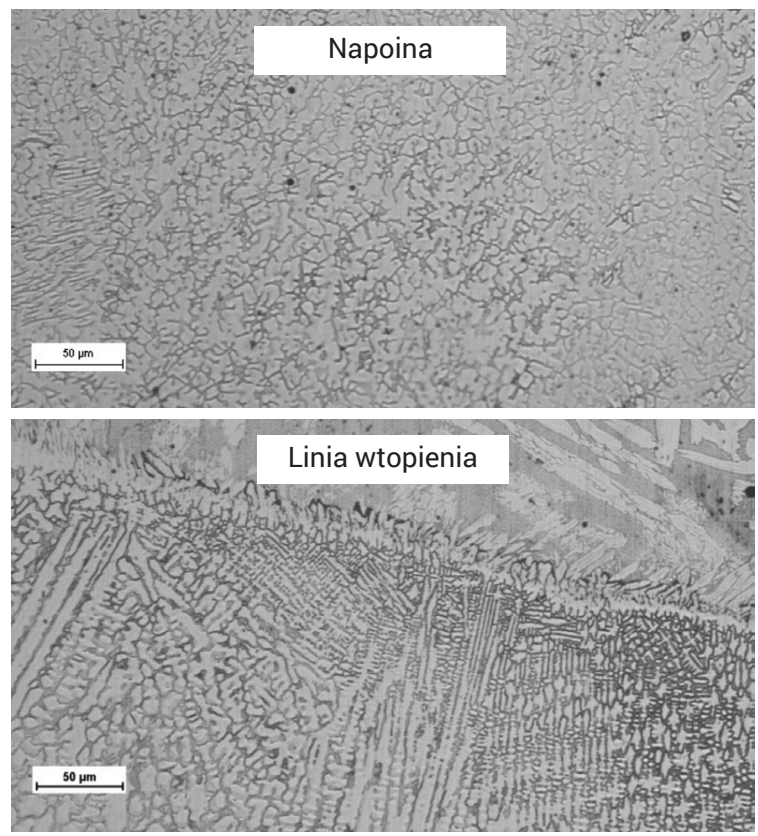
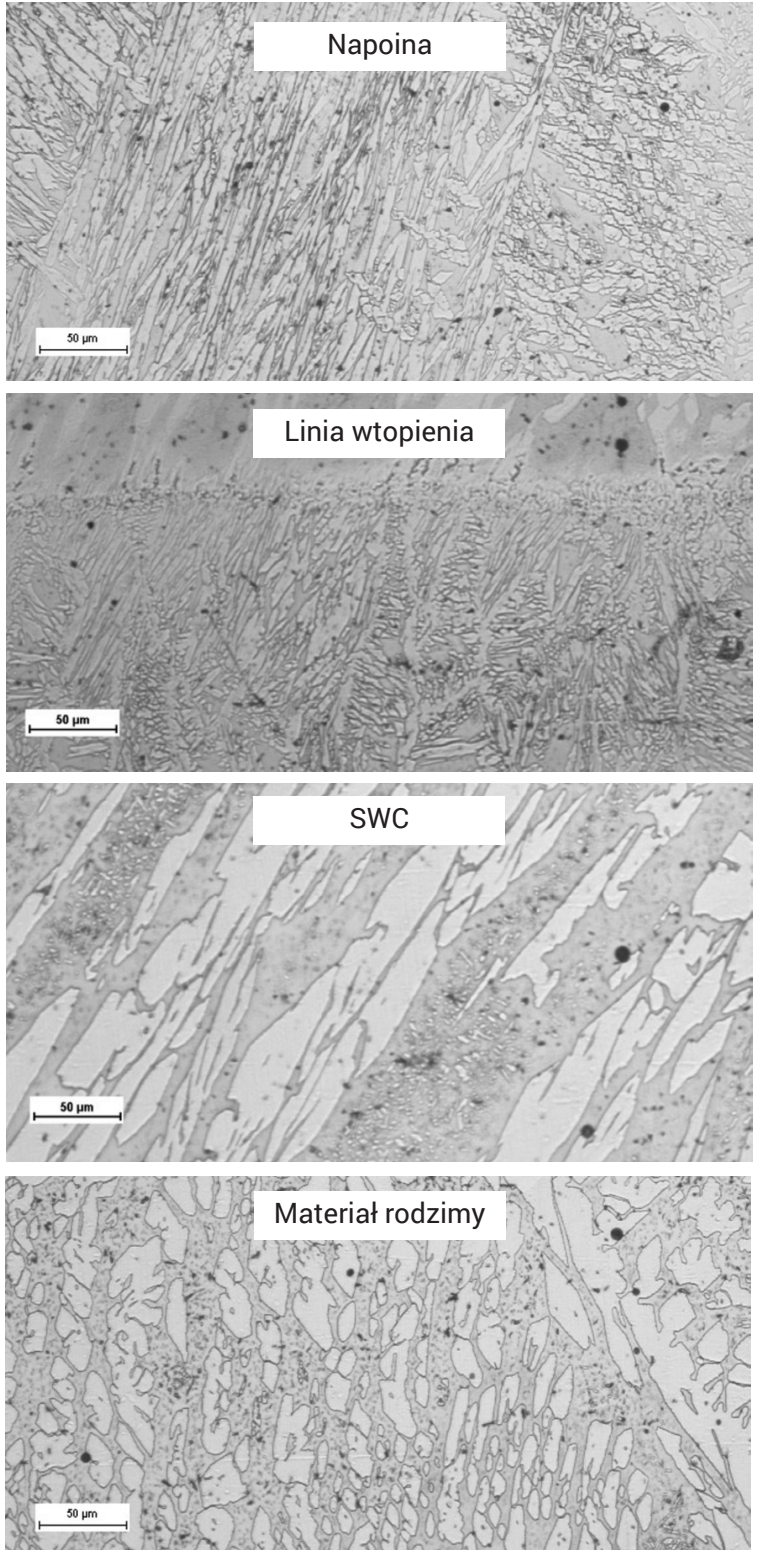

Rys. 8. Mikrostruktury napion uzyskanych metodą MAG; przygotowanie do napawania poprzez żłobienie elektrodą otuloną

Fig. 8. Microstructure padding weld obtained MAG; prepared for weIding gouging through coated electrode
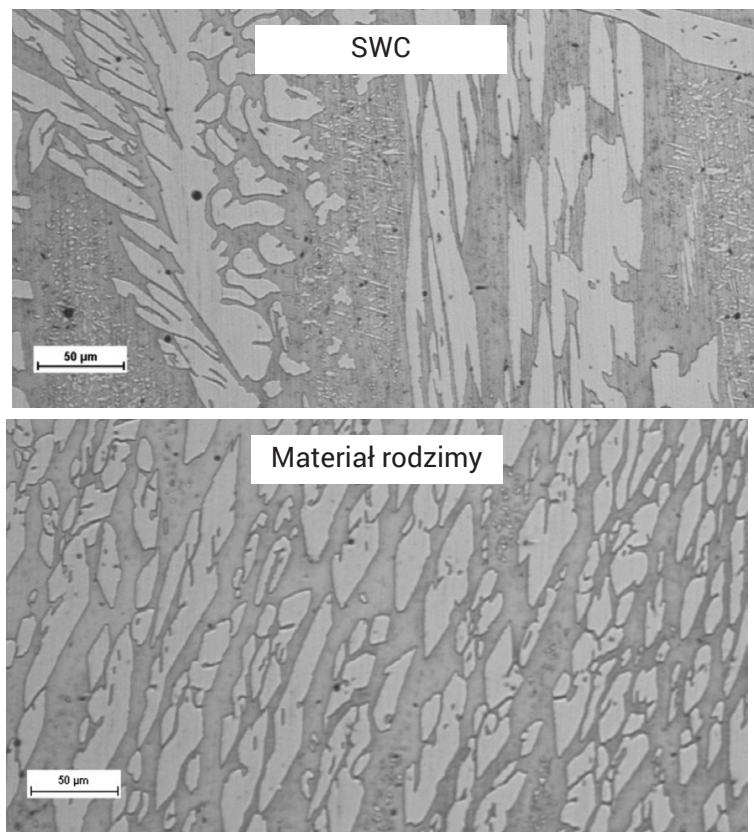

Rys. 9. Mikrostruktury napoin uzyskanych metodą MAG; przygotowanie do napawania poprzez żłobienie elektro-powietrzne Fig.9. Microstructure padding weld obtained MAG; prepared for welding through electro-air gouging 


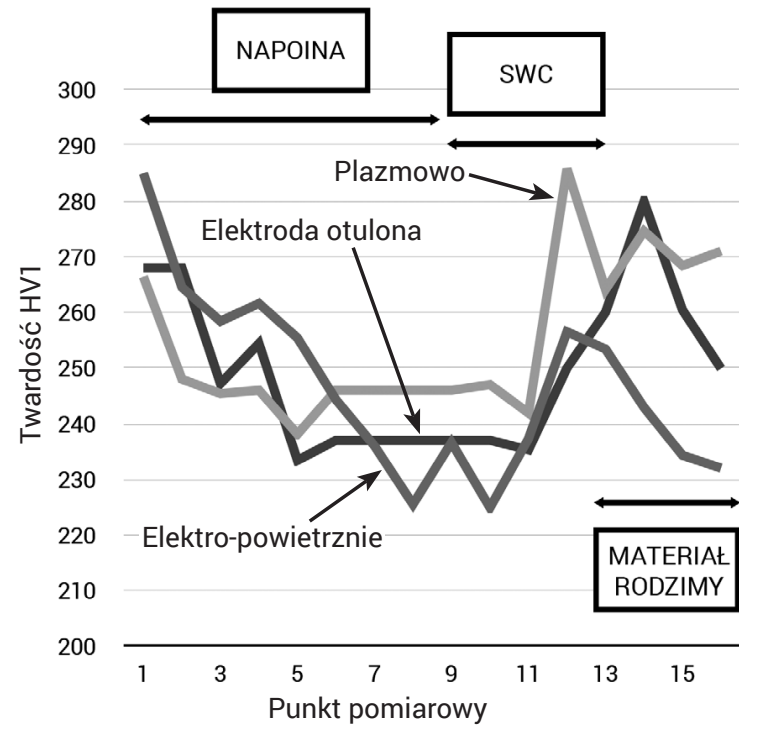

Rys. 10. Rozkład twardości w badanych napoinach

Fig.10. Distribution of the hardness of the test padding weld

\section{Podsumowanie}

Ze względu na strukturę dwufazową ferrytyczno-austenityczną oraz na wymaganą niską zawartość węgla w materiale (ok. 0,03\%) staliwo duplex GX2CrNiMoCu25-6-3-3 jest trudnym materiałem do spawania. Materiały dodatkowe muszą być dopasowane do składu chemicznego materiału rodzimego. Przy zakładanym braku obróbki cieplej po spawaniu powinno się dobrać materiał dodatkowy ze zwiększoną zawartością niklu [8]. Proces spawania nie wpłynął w znaczny sposób na zmiany w materiale rodzimym oraz w SWC, co może wskazywać na prawidłowy dobór materiałów dodatkowych do procesu napawania. Została zachowana struktura dwufazowa ferrytyczno-austenityczna w materiale rodzimym oraz w SWC. Napoina również charakteryzowała się dwufazową strukturą, w dodatku drobnoziarnistą. Może to wskazywać na bardzo dobre parametry wytrzymałościowe oraz odporność korozyjną złącza spawanego. Parametry prądowo-napięciowe spawania pozwoliły uzyskać prawidłowy przetop, przy jednoczesnym małym wymieszaniu z materiałem rodzimym. Ilość wprowadzonego ciepła do złącza nie wywołała istotnych zmian strukturalnych w materiale rodzimym oraz w SWC, co może świadczyć o zachowaniu odpowiednich parametrów wytrzymałościowych podczas eksploatacji elementu naprawianego. Uzyskane wartości twardości po napawaniu naprawczym wykazały wartości zbliżone do twardości materiału rodzimego, co jest istotne z punktu widzenia prowadzonych napraw. Odnotowano jedynie niewielki wzrost wartości twardości w górnej części napion w stosunku do materiału rodzimego. Uzyskane napoiny posiadają barwę zbliżoną do barwy materiału rodzimego, co wskazuje na prawidłowy dobór parametrów spawania oraz materiałów dodatkowych do naprawy i ma istotny wpływ na możliwość zastosowania przedstawionej technologii w naprawach odlewów staliwa typu duplex w warunkach przemysłowych.

\section{Literatura}

[1] Knaginin G., Staliwo: metalurgia i odlewnictwo, wyd. Śląsk, Katowice 1977r.

[2] Staronka A., Zarys metalurgii i odlewnictwa staliwa cz. 1 Metalurgia, AGH, Kraków, 1986r.

[3] Mistur L., Spawanie i napawanie w naprawach części maszyn i konstrukcji metalowych, Wyd. KaBe, Krosno, 2003r.

[4] Nowacki J., Stal duplex i jej spawalność, Wyd. NaukowoTechniczne, Warszawa, 2009r.

[5] Practical guidelines for the fabrication of duplex stainless steel, IMOA, London, 2014r.

[6] Stradomski Z., Stachura S., Dyja D., Zyska A., Technologiczne problemy wytwarzania masywnych odlewów ze staliwa duplex $\mathrm{w}$ aspekcie optymalizacji procesu produkcyjnego, Archiwum Odlewnictwa, 17/2005, s. 287-292.
[7] Spawanie stali nierdzewnych, Eurolnox, Bruksela, 2002r.

[8] Karlsson L., Spawanie stali duplex - przegląd aktualnych zaleceń, Biuletyn Instytutu Spawalnictwa, 5/2012, s. 48-60.

[9] Meka K., Wpływ azotu na kształt i jakość napoin układanych metodą GMA, Przegląd Spawalnictwa, 12/2000, s. 7-11.

[10] Meka K., Własności mechaniczne połączeń ze stali duplex, Przegląd Spawalnictwa, 11/2003, s. 7-10.

[11] Przetakiewicz W., Tomczak R., Niektóre aspekty spawalności ferrytyczno-austenitycznych stali typu duplex i superduplex, Przegląd Spawalnictwa, 3/1995, s. 1-6.

[12] Norma PN-EN 10283:2010: Odlewy ze staliwa odpornego " na korozję.

[13] Badania własne. 